\title{
Economics of Ginger Production in Aurangabad District of Maharashtra
}

\author{
S. E. Shinde*, R. D. Shelke and G. M. Bodakhe \\ Department of Agricultural Economics, College Agriculture, Latur, India \\ *Corresponding author
}

\begin{abstract}
A B S T R A C T
\section{Keywords}

Production of ginger, Cost return, Profitability of ginger

\section{Article Info}

Accepted:

07 November 2020

Available Online:

10 December 2020

The present study entitled, 'Economics of production of Ginger in Aurangabad district of Maharashtra' is based on a sample of 90 Ginger growers drawn from Sillod and Kannad tahsils of Aurangabad district. The study was based on both primary and secondary data. Primary data were collected through personal interview method from farmers, with the help of well-structured and pretested questionnaire exclusively designed for the study. The data collected from ginger growers by personal interview method with the help of pretested interview schedule and pertaining for the year 2019-2020. The production was 132.21 quintal per hectare. Total gross returns from ginger cultivation was obtained 652044.44 quintal per hectares. Total cost of cultivation was Rs. 299806.14. The share of cost-A and cost-B in cost-C was Rs. 182399.89 and Rs. 291830.68 respectively in ginger cultivation. Farm business income Rs.469644.55, Family labour income Rs.360213.76 net profit Rs. 352238.3, the benefit-cost ratio was 2.1. Per quintal cost of production was Rs. 2267.65. Net return in ginger production was high, hence the pre assigned hypothesis viz. Ginger is profitable crop.
\end{abstract}

\section{Introduction}

Among all the spice crops ginger is one of the principal spice crops not only in India but in the entire world which gives valuable foreign exchange for the country. India is the larger producer and exporter to more than 50 countries.

The scientific name of ginger is Zingiber officinale. It belongs to Zingiberaceae family. Native from south eastern Asia. The plant also known as shringavera.

\section{Use of ginger}

The aroma of ginger is pleasant and spicy and the flavour penetrating, pungent, slightly biting due to antiseptic or pungent compounds present in it. These properties make if indispensable in the manufacture of a number of food products like ginger bread, confectionery, gingerale, curry powders, certain curried meats, table sauces, in the pickling and in the manufacture of certain soft drinks like cordials, ginger cocktail, carbonated drinks, bitters, etc. Ginger is also used for the manufacture of ginger oil, oleoresin, essence, tinctures etc. Ginger 
preserved and ginger candy prepared from green or fresh ginger are quite a favourite of many and in great demand.

\section{Materials and Methods}

The sampling technique followed was purposive Multistage sampling procedure was adopted for selection of district, tehsils, villages and the Ginger growers. The sampling procedure adopted for the study is given below. At first stage Aurangabad district was selected purposively selected. In second stage two tehsils viz. Kannad and Sillod was selected. In Third stage from each tehsil three villages was selected. List of farmer Ginger growers was collected from revenue record of each village and from each village 15 cultivator's growing Ginger will be selected constituting a total sample size 90 .

The study was based on both primary and secondary data. Primary data were collected through personal interview method from farmers, with the help of well-structured and pretested questionnaire exclusively designed for the study. The data collected from ginger growers by personal interview method with the help of pretested interview schedule and pertaining for the year 2019-2020.

\section{Analytical tools}

\section{Estimation of costs and returns}

Cost A: Includes the costs on account of hired human labour, bullock labour, machinery charges, value of manures, value of fertilizers, value of seedling, irrigation charges, plant protection charges, land revenue, depreciation and repairs, interest on working capital etc.

Cost-B: Cost-B = Cost ' $A$ ' + rental value of land + interest on fixed capital.
Cost-C: Cost-C $=$ Cost ' $\mathrm{B}$ ' + imputed value of family labour.

\section{Results and Discussion}

\section{Per hectare physical input and output of ginger farm}

Per hectare utilization of physical input and output in ginger cultivation is presented in Table 1 revealed that, 37.36 and 15.22 mandays of hired male and family male labour was utilized on ginger farm. Similarly 40.85 man days and 12.66 man days hired and family female labour was utilized. Average 3.3 pairs of bullock is used to perform various operation of ginger and average 11.03 hours machine labours was use on ginger farm for one hectare of ginger field.

The utilization of seed rhizome was 16.16 quintals for one hectares of ginger farm. Regarding the manures 3.18 tons of farm yard manure was used in ginger production process. Ginger also utilized Biofertilizers, water soluble fertilizers and Chemical fertilizers i.e. 91.24, 79.38 and $680.16 \mathrm{~kg}$ were applied to ginger crop for one hectare of ginger farm. The use of plant protection chemicals such as insecticides was 2.82 lit, fungicides 2.88 lit and 3.39 lit of herbicides for per hectares of ginger. The combined effect of above inputs was reflected in output and it is observed that per hectare 132.21 quintals total fresh ginger rhizomes has harvested.

\section{Cost of cultivation of ginger farm}

The information on various items of cost of cultivation of Ginger is presented in Table 2. The data revealed that, per hectare total cost of cultivation is worked out that cost-C was Rs.299806.14 for Ginger cultivation, in which the contribution of cost-A and cost-B was 60.83 per cent and 97.33 per cent respectively. 
In different items of the expenditure, Rental value of land worked out Rs.108640.70 constituting (36.23) per cent of the total cost which is, predominant because higher yield and prices of ginger. Among the material cost contribution of rhizome material cost is prominent one i.e. Rs. 54620.55 in production which is (18.21) per cent because cost of rhizome is very high.

Expenditure on Fertilizers was Rs.32424.87 which constituted (10.81) per cent, because to increase the yield selected farmers use more fertilizers. In different items in working capital manure cost Rs. 21944.31 constituting (7.31) per cent, Plant Protection Rs. 18732.45 constituting (6.24) per cent, Interest on working capital Rs. 20827.46 constituting (6.54) per cent, irrigation charge Rs. 7499.11 constituting (2.50) per cent, depreciation on capital assets Rs. 1250.79 constituting (0.41) per cent and land revenue Rs. 200.23 constituting (0.06) per cent of the total cost.

Expenditure on labour cost, hired human labour cost Rs. 21599.44, Family labour cost Rs. 7759.99 machine labour cost Rs. 2235.55 and bullock labour cost Rs. 1155 were the cost collectively contributed (7.19) per cent, (2.57) per cent, (0.74) per cent, and (0.38) per cent of the total cost respectively.

Table.1 Per hectare physical input and output of ginger farm (Unit/ha)

\begin{tabular}{|c|c|c|c|}
\hline Sr. No. & Particulars & Unit & Average \\
\hline & INPUT & & \\
\hline \multirow[t]{3}{*}{1.} & Hired human labour & man days & \\
\hline & Male & & 37.36 \\
\hline & Female & & 40.85 \\
\hline \multirow[t]{3}{*}{2.} & Family human labour & man days & \\
\hline & Male & & 15.22 \\
\hline & Female & & 12.66 \\
\hline 3. & Bullock labour & pair days & 3.3 \\
\hline 4. & Machine labour & hours & 11.03 \\
\hline 5. & Rhizomes & qtl & 16.16 \\
\hline 6. & Manures & ton & 3.18 \\
\hline \multirow[t]{4}{*}{7.} & Fertilizer & & \\
\hline & Bio fertilizer & $\mathrm{kg}$ & 91.24 \\
\hline & Water soluble & $\mathrm{kg}$ & 79.38 \\
\hline & Chemical Fertilizer & $\mathrm{kg}$ & 680.16 \\
\hline \multirow[t]{4}{*}{8.} & Plant Protection & & \\
\hline & Insecticides & lit & 2.82 \\
\hline & Fungicides & lit & 2.88 \\
\hline & Herbicides & lit & 3.39 \\
\hline 9. & OUT PUT & & 132.21 \\
\hline
\end{tabular}


Table.2 Per hectare cost of cultivation of Ginger crop (Rs/ha)

\begin{tabular}{|c|c|c|c|}
\hline Sr. No. & Particular & Amount & Per cent \\
\hline \multirow[t]{3}{*}{1.} & Hired human labour & & \\
\hline & Male & 11530 & 3.84 \\
\hline & Female & 10069.44 & 3.35 \\
\hline 2. & Machine labour & 2235.55 & 0.74 \\
\hline 3. & Bullock labour & 1155 & 0.38 \\
\hline 4. & Rhizome & 54620.55 & 18.21 \\
\hline 5. & Manure & 21944.31 & 7.31 \\
\hline \multirow[t]{5}{*}{6.} & Fertilizer & & \\
\hline & Biofertilizer & 7635.7 & 2.54 \\
\hline & Water soluble & 10463.22 & 3.48 \\
\hline & Chemical fertilizer & 14325.95 & 4.77 \\
\hline & Sub total & 32424.87 & 10.81 \\
\hline \multirow[t]{5}{*}{7.} & Plant protection & & \\
\hline & Insecticides & 7952.82 & 2.65 \\
\hline & Fungicides & 5074.71 & 1.69 \\
\hline & Herbicides & 5704.92 & 1.90 \\
\hline & Sub total & 18732.45 & 6.24 \\
\hline 8. & Irrigation & 7499.11 & 2.50 \\
\hline 9. & Working capital & $160211 . .27$ & 53.43 \\
\hline 10. & Interest on working capital @ 13\% & 20827.46 & 6.94 \\
\hline 11. & Land revenue & 200.23 & 0.06 \\
\hline 12. & Depreciation@10\% & 1250.79 & 0.41 \\
\hline 13. & Cost-A ( $\Sigma 1$ to12) & 182399.89 & 60.83 \\
\hline 14. & Rental value of land & 108640.70 & 36.23 \\
\hline 15. & Interest on fixed capital @ 10\% & 790.09 & 0.26 \\
\hline 16. & Cost-B ( $\Sigma 13$ to16) & 291830.68 & 97.33 \\
\hline \multirow[t]{3}{*}{17.} & Family labour & & \\
\hline & Male & 4586.66 & 1.52 \\
\hline & Female & 3173.33 & 1.05 \\
\hline 18. & Cost-C ( $\Sigma 16$ to18) & 299806.14 & 100 \\
\hline
\end{tabular}


Table.3 Per hectares profitability in Ginger production (Rs/ ha)

\begin{tabular}{|c|l|c|}
\hline Sr. no. & Particular & Amount \\
\hline $\mathbf{1 .}$ & Gross return & 652044.44 \\
\hline $\mathbf{2 .}$ & Cost-A & 182399.89 \\
\hline $\mathbf{3 .}$ & Cost-B & 291830.68 \\
\hline $\mathbf{4 .}$ & Cost-C & 299806.14 \\
\hline $\mathbf{5 .}$ & $\begin{array}{l}\text { Farm business income } \\
\text { (Gross return minus Cost-A) }\end{array}$ & $\mathbf{4 6 9 6 4 4 . 5 5}$ \\
\hline $\mathbf{6 .}$ & $\begin{array}{l}\text { Family labour income } \\
\text { (Gross return minus Cost }-\mathrm{B})\end{array}$ & $\mathbf{3 6 0 2 1 3 . 7 6}$ \\
\hline $\mathbf{7 .}$ & $\begin{array}{l}\text { Net Profit } \\
\text { (Gross return minus Cost-C) }\end{array}$ & $\mathbf{3 5 2 2 3 8 . 3}$ \\
\hline $\mathbf{8 .}$ & $\begin{array}{l}\text { Benefit- Cost ratio } \\
\text { (Gross return divided by Cost-C) }\end{array}$ \\
\hline $\mathbf{9 .}$ & $\begin{array}{l}\text { Per quintal cost of production } \\
\text { (Cost-C divided total harvested fingers) }\end{array}$ & $\mathbf{2 2 6 7 . 6 5}$ \\
\hline
\end{tabular}

\section{Profitability of ginger production}

Per hectare profitability of ginger crop was analyzed and present Table 3 . It is revealed that per hectares total gross returns from ginger cultivation was obtained 652044.44 quintal per hectares. While, total cost of cultivation was Rs 299806.14. The share of cost-A and cost-B in cost-C was Rs. 182399.89 and Rs. 291830.68 respectively in ginger cultivation.

The various measures of income were worked out at particular cost level and are also presented in Table 3. Farm business income viz. gross return minus cost-A on the farm was Rs.469644.55. The farm business income is more because of high cost of family human labour. Family labour income i.e. gross return-minus cost-B was estimated to Rs.360213.76 on ginger. The net profit i.e. gross return minus cost-C was arrived at Rs. 352238.3 in ginger. The benefit-cost ratio indicates the return from each rupee investment in Ginger cultivation. The results revealed that the $\mathrm{B}$ : $\mathrm{C}$ ratio viz. gross return divided by cost- $\mathrm{C}$ obtained was 2.1 for ginger cultivation i.e. Spending Rs. 1, they got back
Rs. 2.1 in ginger cultivation. Per quintal cost of hence the pre assigned hypothesis viz. Ginger is profitable crop.

In conclusion the different items of the expenditure, Rental value of land worked out (36.23) per cent of the total cost which is, predominant because higher yield and prices of ginger. Among the material cost contribution of rhizome material cost is prominent one in production which is (18.21) per cent because cost of rhizome is very high.

Per hectare total cost of cultivation found that cost-C was Rs.299806.14 for Ginger cultivation, in which the share of cost-A and cost-B was 60.83 per cent and 97.33 per cent respectively. The contribution of cost-A and cost-B in cost-C was Rs. 182399.89 and Rs. 291830.68 respectively in ginger cultivation. Farm business income Rs.469644.55, Family labour income Rs.360213.76 net profit Rs. 352238.3 , the benefit-cost ratio was 2.1. Per quintal cost of production was Rs. 2267.65. Net return in ginger production was high, hence the pre assigned hypothesis viz. Ginger is profitable crop enterprise. 


\section{References}

Bhat B. S., Murthy C and Yusuf M. (2012) Economics of production of ginger in Uttara Kannada district of Karnataka. International Research Journal of Agricultural Economics and Statistics 3 (1): 181-185.

Changule R.B., Mane U.S., Gharge S.H. and Kolekar P.L (2011) Economics of ginger production in Latur district of Maharashtra. International Journal of Commerce and Business Management
4 (2): $245-24$.

Kadam A.S., Suryawanshi R.R., Dhengale S.S. and Shinde H.R. (2019) Economic analysis of production of ginger in Sangli district of Maharashtra. International Journal of Chemical Studies,.7 (6): 1456-1460.

Mathew M., Vani N. and Aparna B. (2016) Economics of Production of Ginger in Wayanad District of Kerala, India. Asian Journal of Research in Marketing 63(3): 627-632.

\section{How to cite this article:}

Shinde, S. E., R. D. Shelke and Bodakhe, G. M. 2020. Economics of Ginger Production in Aurangabad District of Maharashtra. Int.J.Curr.Microbiol.App.Sci. 9(12): 549-554.

doi: https://doi.org/10.20546/ijcmas.2020.912.066 